\begin{tabular}{|l|l|l||}
\hline \multicolumn{2}{|c|}{ PublisherInfo } \\
\hline \hline PublisherName & $:$ & BioMed Central \\
\hline \hline PublisherLocation & $:$ & London \\
\hline \hline PublisherImprintName & $:$ & BioMed Central \\
\hline \hline
\end{tabular}

\title{
The ESTs from Brazil
}

\begin{tabular}{|l|l|l||}
\hline \multicolumn{2}{|c|}{ ArticleInfo } \\
\hline \hline ArticleID & $:$ & 3832 \\
\hline \hline ArticleDOI & $:$ & $10.1186 /$ gb-spotlight-20001115-03 \\
\hline \hline ArticleCitationID & $:$ & spotlight-20001115-03 \\
\hline \hline ArticleSequenceNumber & $:$ & 269 \\
\hline \hline ArticleCategory & $:$ & Research news \\
\hline ArticleFirstPage & $:$ & 1 \\
\hline \hline ArticleLastPage & $:$ & 2 \\
\hline \hline & & RegistrationDate : 2000-11-15 \\
\hline ArticleHistory & $:$ & OnlineDate \\
\hline \hline ArticleCopyright & $:$ & BioMed Central Ltd2000-11-15 \\
\hline \hline ArticleGrants & $:$ & \\
\hline \hline ArticleContext & $:$ & 130591111 \\
\hline \hline
\end{tabular}




\section{William Wells}

Email: wells@biotext.com

Guesses about the number of genes in the human genome vary wildly and may continue to do so even when the entire genome sequence is available. Computational methods for picking out exons that are scattered amongst vast introns yield both false positives and false negatives. This has prompted a Brazilian sequencing group to generate a quarter of a million open reading frame (ORF) expressed sequence tags (ORESTES), as they report in the November 7 Proceedings of the National Academy of Sciences (Proc Natl Acad Sci USA 2000, 97:12690-12693). Unlike other expressed sequence tags (ESTs), ORESTES do not favor one end of a transcript or another. The new collection of ORESTES includes $50.5 \%$ of the 545 genes annotated from the complete sequence of chromosome 22, but also predict a further 219 genes on chromosome 22 that were not annotated. Updated searches show that 171 of these 219 sequences are also now represented by ESTs from other projects deposited in dbEST.

\section{References}

1. Guesses, anyone?, [http://www.genomebiology.com/SpotlightRedirect.asp?Link=20000523-1.xml]

2. Shotgun sequencing of the human transcriptome with ORF expressed sequence tags.

3. Proceedings of the National Academy of Sciences, [http://www.pnas.org/]

4. The DNA sequence of human chromosome 22 .

5. dbEST, [http://www.ncbi.nlm.nih.gov/dbest/]

This PDF file was created after publication. 